\title{
Domestikasi Peran Cendekiawan dan Perkembangan Sosiologi di Indonesia
}

\author{
Nasikun
}

\section{Pendahuluan: Kisah Seorang Pangeran}

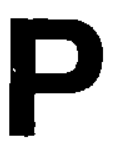

ada awal tahun 1964, sebuah proyek penelitian paling besar dan berpengaruh di dalam sejarah ilmuilmu sosial diselenggarakan dengan pembiayaan raksasa (4 sampai 5 juta dollar AS) di bawah sponsor suatu biro penelitian khusus (Special Operation Research Office) di lingkungan Angkatan Bersenjata Amerika Serikat. Proyek Penelitian tersebut yang kemudian diberi nama Proyek $\mathrm{Ca}$ melot, diselenggarakan dengan tujuan untuk mengungkapkan sebab-sebab pemberontakan dalam negeri dan revolusi di beberapa negara sedang berkembang, khususnya di negara-negara Amerika Latin. Pembaca yang mengetahui bahwa proyek itu ternyata kemudian dihentikan di tengah jalan melalui suatu keputusan kontroversial Departemen Pertahanan Amerika Serikat tentu segera dapat menduga bahwa dibalik keputusan tersebut pastilah terdapat alasan yang mendasar. Sesungguhnya, mendasari tujuan penelitian tersebut sebenarnya adalah pemikiran sangat pragmatis di dalam kerangka politik luar negeri Amerika Serikat: bahwa masalah-masalah hubungan intemasional yang menghangat kala itu seyogyanya tidak diselesaikan melalui penyelesaian militer (baik melalui "perang dingin" maupun "perang panas") melainkan hendaknya diselesaikan melalui penyelesaian politik, dan penelitian tersebut diselenggarakan dengan tujuan untuk mengumpulkan data-data empiris bagi penyusun politik luar negeri Amerika Serikat yang demikian. Dari surat edaran yang dikeluarkan untuk menarik para ahli untuk berpartisipasi di dalam proyek itu lebih lanjut terungkap, bahwa di samping tujuan resmi seperti sudah disebutkan di atas proyek penelitian yang diberi label nama seorang pangeran itu ternyata mempunyai tujuan lain yang lebih praktis: yakni mengidentifikasi tindakan-tindakan yang dapat diambil oleh pemerintah Amerika Serikat mengendalikan kondisi-kondisi yang dinilai dapat menjadi sebab dari kemungkinan timbulnya pembrontakan dalam negeri di negara-negara "sahabat" (termasuk di antaranya Indonesia dan beberapa negara Amerika Latin) yang menjadi obyek penelitian Proyek Camelot. Surat edaran yang sama juga menyatakan bahwa Angkatan Bersenjata Amerika Serikat memiliki misi penting untuk membantu penyelenggaraan "pembinaan bangsa" (nation building) di negara-negara sedang berkembang dan membantu pemerintah-pemerintah negara-negara sahabat mengatasi pemberontakan-pemberontakan dalam negeri mereka 
(Dahrendorf, 1968).

Diawali dengan penolakan Johan Galtung seorang ahli teori konflik berkelahiran Norwegia, untuk mengambil bagian di dalam Proyek Cambelot dengan alasan bahwa peran Angkatan Bersenjata Amerika Serikat sebagai sponsor Proyek Camelot akan lebih menggoncangkan daripada memelihara perdamaian di negara-negara sedang berkembang, tiada terduga sebelumnya oleh siapa pun, proyek penelitian yang memiliki tujuan amat "mulia" itu ternyata telah menyulut terjadinya kekacauan politik di beberapa negara Amerika Latin yang semula justru ingin dicegah. Menyusul terjadinya serangkaian demokrasi anti Amerika Serikat di beberapa ibukota negara-negara Amerika Latin yang mengutuk Proyek Camelot sebagai kegiatan spionase berselubung, resolusi senator Fulbright, Morse Fulbright, Morse, dan McCarthy yang meminta Senat untuk menyelidiki Proyek Camelot, serta peselisihan antara Departemen Luar Negeri dan Departemen Pertahanan Amerika Serikat tentang yurisdiksi penyelenggaraan Proyek Camelot, maka pada bulan Juli 1965 Departemen Pertahanan Amerika Serikat terpaksa harus menghentikan proyek penelitian yang sangat "mahaf" itu.

Dengan dihentikan Proyek Camelot tamatlah sudah riwayat sebuah proyek penelitian paling kontroversial di dalam sejarah penelitian ilmu-ilmu sosial, akan tetapi tidaklah demikian halnya dengan Camelot sebagai suatu skandal keilmuan. Perdebatan pro dan kontra yang sengit dan seringkali bersifat sangat emosional tentang Proyek Camelot dan kematiannya yang tiba-tiba justru baru terjadi sesudah ia tiada. Dan mereka yang arif niscaya mengerti bahwa perdebatan tersebut pastilah mengenai. masalah paling pelik di dalam ilmu pengetahuan: yakni, masalah etika, moral, dan pertimbangan nilai di dalam hubungan antara teori dan praksis. Sebenarnyalah, perdebatan sengit yang terjadi sebagai reaksi terhadap skandal Camelot tidaklah meleset memang berkisar di seputar dasardasar etik, moral, dan pertimbangan nilai dari Proyek Camelot. Barangkali belum pernah terjadi di dalam sejarah penelitan ilmuilmu sosial, termasuk sosiologi, masalah etika, moral, dan pertimbangan nilai di dalam hubungan antara teori dan praksis sesudah tahun 1915, ketika untuk pertama kalinya Max Weber melontarkan isyu tentang. value free science, memperoleh bentuk penagkapannya yang paling konkrit yang terjadi di dalam Proyek Camelot.

\section{Problem Epistemologi Peran Cendekiawan}

Kisah tentang Proyek Camelot saya sajikan panjang lebar di sini pertama-tama untuk menunjukkan sebuah bukti autentik betapa ditengah hingar-bingar kehidupan modern-industrial, tanpa landasan etis, dan pertimbangan-pertimbangan nilai, ilmu-ilmu pengetahuan empiris-analitis dapat dengan sangat mudah tergelincir menjadi tidak lebih daripada sebagai "teknik-teknik" untuk suatu piecemeal engineering penyelesaian masalah-masalah praktis bagi kepentingan suatu kelompok atau kelas tertentu. Di dalam perumusan lain, di dalam masyarakat modern industrial, di mana ilmu pengetahuan, teknologi, industri, dan birokrasi berkaitan sangat eratnya satu sama lain, tanpa landasan etis, moral, dan pertimbangan-pertimbangan nilai hubungan antara teori dan praktis seringkali hanya dapat menyatakan dirinya tidak lebih daripada sebagai aplikasi rasional dari teknik-teknik yang didukung oleh ilmu pengetahuan empiris-analisis (Habermas, 1976). Di dalam proses yang demikian, potensi sosial ilmu pengetahuan bagi orientasi tindakantindakan pencerahan (enlightened actions) 
akan semakin surut menjadi tidak lebih daripada sebagai instrumen kelas tertentu untuk mengendalikan lingkungan eksternal kehidupan umat manusia. Dan selama ilmu-ilmu pengetahuan empiris-analisis terutama memusatkan perhatian mereka pada penyelesaian yang bersifat piecemealatas masalah-masalah berjangka pendek, maka hasil-hasil yang akan mereka capai pun hanya akan merupakan suatu proses rigresi yang tiada berujung: di mana penyelesaian atas suatu masalah akan menciptakan atau melahirkan suatu masalah atau masalahmasalah baru proses rigresi yang tiada berujung: di mana penyelesaian atas suatu masalah akan menciptakan atau melahirkan suatu masalah atau masalah-masalah baru.

Lebih daripada itu, skandal Camelot saya sajikan panjang dan lebar di sini sebagai sumber inspirasi bagi suatu refleksi kritis mengenai problema epistemologis pengembangan ilmu pengetahuan di dalam konteks masyarakat modern-industrial. Kontroversial Proyek Camelot sengaja saya hidupkan kembali di sini sebagai bahan kritis tentang peran cendekiawan di belakang perkembangan ilmu pengetahuan. Melalui pengungkapan kembali Proyek $\mathrm{Ca}$ melot, saya ingin mengundang para peserta sidang pembaca terhormat ini untuk merenungkan kembali peran kita sebagai cendekiawan di dalam suatu negara yang sedang mempersiapkan diri memasuki tahapan transisi industrial. Beberapa diantara pertanyaan-pertanyaan paling penting yang harus kita jawab adalah: (1) di dalam suatu masyarakat yang sedang membangun, di mana para cendekiawan seharusnya memilih tempat berdiri?; (2) di atas dasar pertimbangan apa saja pilihan itu harus mereka ambil?; dan (3) di dalam posisi yang mereka pilih ini, bagaimana para cendekiawan seyogyanya berusaha mengelola ketegangan-ketegangan yang terjadi antara sumber eksistensi "genetik" dan komitmen "generik" mereka?

\section{Peran Cendekiawan Dalam Pembangunan?}

Di dalam melakukan refleksi kritis mengenai peran dan tanggungjawab cendekiawan (intellectuals) di dalam proses pembangunan, ialah sangat penting untuk memulainya dengan mempersoalkan secara kritis konsep "obyektivitas" di dalam ilmu pengetahuan. Adalah para ahli sosiologi pengetahuan Marxist yang pertama kali melakukan refleksi kritis mengenai eksistensi dan peran mereka sebagai cendekiawan di dalam masyarakat dengan menunjukkan bahwa semua pengetahuan memiliki sumber eksistensial masing-masing di dalam konteks struktural mereka merumuskannya, dan bahwa seorang cendekiawan pada dasarnya senantiasa memainkan peranan sebagai "juru bicara" dari suatu kelompok atau kelas sosial yang kepentingan-kepentingannya mereka artikulasikan. Di dalam ungkapan Gramsci, yang menurunkan pemikirannya dan Marx dan Lukacs, setiap kelas sosial memerlukan kelompok cendekiawan masing-masing, yang sebaliknya harus memiliki kelas sosial tempat mereka menjadi bagian organik daripadanya (Konrad. 1979).

Di dalam pandangan kaum Marxist, peranan cendekiawan adalah merumuskan kepentingan-kepentingan dan ideologi dari suatu kelas sosial. Dengan perkataan ini, dalam pandangan mereka, kaum cendekiawan tidaklah lebih daripada teknisi-teknisi yang memainkan peran "genetik" merumuskan ideologi yang ditentukan oleh dan melayani kepentingan suatu kelas sosial tertentu: yang didalam stelsel kapitalis, ditentukan oleh dan melayani kepentingan kelas pemilik kapital. Sebaliknya mereka sangat percaya bahwa peran "genetik" 
cendekiawan di atas kepentingan kelas, sebagaimana yang bisa diyakini mereka yang menyebut diri sebagai cendekiawan, hanya akan merupakan sebuah mitos kecuali di tangan mereka yang mampu mentransformasikan diri mereka ke dalam posisi sebagai pembela kepentingan kaum buruh di dalam masyarakat tanpa kelas.

Para pengritik sosiologi pengetahuan Marxist mengajukan argumen bahwwa pandangan Marxist terlalu berlebihan di dalam menyederhanakan gabungan antara pengetahuan dan sumber eksistensi pengetahuan. Kritik tersebut memiliki dua sasaran berikut: di satu pihak ia mempertanyakan keabsyahan proposisi Marxist yang melihat kedudukan cendekiawan di dalam struktur sosial sebagai satu-satunya sumber eksistensial pengetahuan, sementara di lain fihak ia menuntut suatu pemahaman yang lebih lengkap mengenai hubungan di antara keduanya.

Berbeda dari Karl Marx, Karl Mannheim berpendapat bahwa kelas sosial bukan merupakan satu-satunya sumber eksistensial dari pengetahuan. Oleh karena itu Mannheim percaya akan terbukanya kemungkinan untuk mengembangkan pengetahuan yang mampu menembus dan berada atas ideologi-ideologi kelas. Di dalam pandangannya, terdapat tiga pilihan peran yang dapat diambil oleh seorang cendekiawan (Mannheim, 1936). Pertama seorang cendekiawan dapat memilih peran sebagai perumus "ideologi" dan pembela kepentingan-kepentingan kelompok atau kelas pennguasa dominan dari tertib sosial yang ada. Sebaliknya, ia dapat juga mengambil posisi dan peras sebagai perumus "utopia" dan pejuang kepentingan-kepentingan kelompok atau kelas yang tersisih. Manheim menyebut state of mind yang demikian sebagai "utopia". Di luar itu, cendekiawan dapat memilih. posisi dan memiliki kemampuan untuk memilih posisi berdiri di atas kepentingan-kepentingan kelas, dan yang oleh karenanya dapat disebut memilih posisi sebagai a free floating intellegentsia.

Pada tingkat perkembangannya saat ini, para cendekiawan (baik yang berwawasan Maxist maupun non-Marxist) sudah tidak lagi memiliki kesulitan untuk menerima proposisi bahwa kesadaran sosial kita seringkali dibatasi oleh kepentingankepentingan kelas. Di lain fihak mereka tidak pula memiliki kesulitan untuk menerima the culture creating activity sebagai peran kecendekiawanan yang paling penting. Tidak mengherankan apabila mereka, kritis terhadap peran genetik mereka sebagai cendekiawan, menjadi sangat biasa pula untuk menarik garis demarkasi yang memisahkan berbagai jenis kegiatan intelektual, dan menolak untuk memberikan label cendekiawan bagi mereka yang karya-karya pemikirannya tidak menghasilkan suatu transendens radikal dari hubunganhubungan kepentingan masyarakat. Derajat kecendekiawanan sebaliknya hanya diberikan kepada mereka yang memiliki pimikiran-pemikiran yang secara kritis menembus tertib sosial yang ada. Di dalam ungkapan Friedrich, ceridekiawan adalah mereka yang tidak hanya memiliki kemampuan untuk mengemban peranan kependetaan (priestly roles) akan tetapi juga kemampuan untuk memikul peranan-peranan "prophetis" atau "kenabian" (prophetic roles); mereka yang memiliki kemampuan mentransformasikan eksistensi genetik mereka sebagai juru bicara dan pembela kepentingan dari suatu kelas tertentu menjadi eksistensi genetik sebagai juru bicara dan pejuang kepentingan-kepentingan kemanusiaan. Semuanya itu pada gilirannya hanya dapat diperoleh sepanjang mereka memiliki komitmen yang kuat pada nilai-nilai dan pengembangan pengetahuan yang bersifat universal di atas keteriakan- 
keteriakan kesejarahan, demi tercapainya suatu kehidupan bersama yang lebih adil, menusiawi, dan bebas, dan demi kesejahteraan umum bagi semua orang. Komitmen pada tercapainya kesejahteraan umum bagi semua orang meski nampak kontradiktoris pada penglihatan pertama, sebaliknya menuntut para cendekiawan untuk senantiasa menaruh perhatian terhadap kepentingan kaum miskin dan terlantar, yang di dalam proses pembangunan oleh karena tempat mereka di pinggiran tertib sosial yang ada acap kali menjadi korban dari perubahanperubahan yang terjadi terlalu cepat

\section{Domestikasi Peran Cendekiawan di Indonesia}

Refleksi kritis mengenai eksistensi genetik dan pemihakan terhadap eksistensi genetik cendekiawan, lebih-lebih perlu senantiasa dilakukan oleh para cendekiawan di dalam satu masyarakat yang sedang membangun menuju transisi industrial. Setidak-tidaknya terdapat dua alasan sangat mendasar mengapa hal itu perlu terus menerus dilakukan. Pertama, meningkatnya spesialisasi cabang-cabang ilmu pengetahuan yang dituntut oleh suatu proses industrialisasi, yang pada gilirannya cenderung mentransformasikan eksistensi generik cendekiawan sebagai agen perubahan sosial yang kritis ke dalam eksistensi genetik mereka mereka sebagai fungsionaris intelektual dari suatu kelas dominan dan dengan demikian semakin kehilangan daya kritis mereka. Kedua, semakin meningkatnya bersamaan dengan dan sepanjang proses industrialisasi jumlah cendekiawan yang terdiri atas para pekerja ahli yang berpendapatan tinggi, sangat berpengaruh, dan dekat dengan pusat-pusat kekuasaan. Seperti halnya dengan yang pertama, situasi yang kedua merupakan konteks sosial yang dapat menghasilkan konse- kuensi yang sama menurunkan eksistensi generik cendekiawan sebagai agen perubahan sosial yang kritis ke dalam eksistensi genetik mereka sebagai fungsionaris intelektual dari kelas penguasa, yang dapat semakin menghilangkan daya kritis mereka sebagai juru bicara dan pejuang kepentingan-kepentingan kelas, kelompok, atau kaum yang tersisih. Di dalam konteks Indonesia, paling sedikit sejak Dekrit Presiden Sukarno tahun 1969, dan terutama sejak tahun 1987 ketika dominasi negara atas masyarakat pada tingkat simbolis dan substansi telah mencapai zenitnya menyusul penerimaan Pancasila sebagai azas tunggal organisasi kemsyarakatan, terhadap kedua alasan itu masih perlu ditambahkan alasan ketiga berupa "domestikasi" (baca: penjinakan) peran cendekiawan oleh negara yang telah terjadi demikian sangat mendalam sehingga mereka yang paling kritis sekali pun tidak mudah memahami dan memilih tempat dan komitmen genetik mereka di dalam masyarakat.

Mengenai yang terakhir para ahli ilmu politk sangat membantu menemukan sumber penjelasannya di dalam karekter sistem politik Indonesia. Kendati d dalam menginterpretasikan sistem Indonesia mereka berbeda pendapat tentang model konseptual yang paling tepat untuk menggambarkannya, mereka bersepakat pendapat bahwa, terutama sejak Orde Baru, peranan negara di dalam kehidupan politik di Indonesia demikian besarnya sehingga tidak tersedia ruang bagi kekuatan-kekuatan politik di luar negara untuk memiliki pengaruh yang besar di dalam penentuan kebajikan publik (baca, a.l., Jackson; King, 1983; dan Macintyre, 1990). Sangat dikuasai oleh obsesi tentang konflik-konflik politik sebagai akibat mobilisasi politik yang luas di penghijauan masa pemerintahan Presiden Sukarno dan runtuhnya Orde Lama, sejak sangat awal, pemerintah 
Orde Baru mengembangkan suatu strategi korporatis yang sangat efektif untuk mengendalikan tuntutan-tuntutan terhadap pemerintahan yang masih sangat muda kala itu oleh suatu spekrum yang sangat luas dari kelompok-kelompok yang ada di dalam masyarakat.

Inti dari strategi yang demikian adalah pengalihan partisipasi politik dari partai politik yang sulit dikendalikan negara, ke dalam berbagai lembaga atau organisasi perkawinan fungsional yang dibentuk atau diotorisasi oleh pemerintah. Demikian dari pembentukan KORPRI (Korp Pegawai Republik Indonesia), kini kita memiliki satu atau lebih organisasi korporatis untuk hampir setiap sektor kehidupan masyarakat yang strategis: pertanian (HKTI), nelayan (HNSI), perubahan (SPSI), bisnis (KADIN), keagamaan (BKAA, MUI, KWI, dan DGI). Daftar itu masih dapat diperpanjang untuk menyebut korporatisasi yang berhasil dilakukan pemerintah Orde Baru di sektorsektor kehidupan yang lain: seperti, hukum (IKADIN), kewanitaan (PKK, Darma Wanita, dll.), pemuda (KNPI, AMPl, dII), olah raga (KONI), dan ilmu pengetahuan melalui pembentukan atau akomodasi berbagai organisasi profesi dari berbagai disiplin ilmu pengetahuan dan organisasi korporatis cendekiawan dari berbagai kelompok dan golongan masyarakat.

Mendasari sistem politik korporatis adalah suatu premis yang menolak pandangan liberal bahwa perbedaan-perbedaan kelas dapat dipecahkan melalui konflikkonflik yang dilembagakan antara berbagai kelompok dan organisasi perwakilan mereka (Gunther, seperti dikutip oleh Mohtar Mas'oed, 1983). Korporatisme, menurut premis itu, pada dasarnya merupakan perwujudan dari upaya unuk menekan pertentangan-pertentangan kelas atau kelompokkepentingan melalui pembentukan organisasi-organisasi korporatik dengan tujuan utama: (1) untuk memelihara harmoni, solidaritas, dan kerjasama di dalam hubungan antara penguasa negara dan massa rakyat, dan (2) untuk menciptakan iklim yang memungkinkan penguasa negara memiliki pengaruh yang langsung dan bewar di dalam proses politik. Di dalam jargon politik Orde Baru, korporatisme pada dasarnya merupakan merupakan perwujudan upaya untuk menciptakan sistem politik yang "stabil dan dinamis", yang bukan secara kebentulan hadir ke tingkat wacana akademis melalui konseptualisasi seorang ahli ilmu politik yang di kemukakan hari menjadi seorang juru bicara yang paling berpengaruh dari organisasi induk yang memayungi semua organisasi korporatis: GOLKAR.

Paralel dengan dan melengkapi strategi pembentukan jaringan organisasi korporatis untuk memotong hubungan antara partai politik dan masyarakat adalah pelaksanaan kebijakan penyederhanaan jumlah partai politik, kebijakan massa mengambang, dan konsensus nasional untuk memperlakukan Pancasila sebagai azas tunggal bagi semua organisasi kemasyarakatan. Bagaikan pedang bermata dua, semua itu memiliki dua fungsi dan konsekuensi yang tidak hanya berbeda akan tetapi juga berlawanan satu dari yang lain. Pertama, semuanya itu memang sangat diperlukan untuk memelihara integrasi masyarakat Indonesia yang majemuk dan sarat dengan mantan konflik-konfilk sosial yang tidak hanya bersifat kronis, akan tetapi juga memiliki potensi dissintegratif sebagaimana telah terbukti dari sejarah perjalanan masyarakat Indonesia sebagai suatu bangsa. Pada saat yang sama, semua itu memiliki konsekuensi langsung berupa terjadinya domestikasi semua aktor masyarakat, tanpa kecuali para cendekiawan dari semua disiplin ilmu pengetahuan. Pada tingkat pertama, domestikasi terjadi melalui struk- 
tur hubungan korporatis antara negara dan masyarakat, yang di dalam hakekat dan dimilikinya, pada dasarnya merupakan hubungan kontraktual untuk menyediakan ganjaran material dan sosial oleh negara sebagai imbalan atas stabilitas dan dukungan politis terhadap kekuasaan negara oleh pimpinan organisasi korporatis. Dengan mensubordinasikan semua organisasi korporatis di bawah kekuasaan negara dan membatasi partisipasi politik hanya melalui organisasi-organisasi korporatis yang dikendalikan oleh negara, penguasa negara memiliki kekuasaan yang besar untuk mengendalikan tuntutan-tuntutan nyaris semua kelompok di dalam masyarakat.

Pada tingkat politis domestikasi antara lain terjadi sebagai konsekuensi tidak langsung dari pelaksanaan kebijaksanaan jumlah partai politik melalui fisi partai-partai Islam menjadi Partai Persatuan Pembangunan (PPP) dan partai-partai nasionalis dan Kristen menjadi Partai Demokrasi Indonesia (PDI). Oleh karakter "politik suku" (ethnic politics) dari semua partai politik yang membentuk keduanya, kebijakan massa mengambang, dan "pembinaan" serta "campur tangan" negara untuk mengendalikan agar kepemimpinan kedua partai itu dipegag oleh tokoh-tokoh partai yang "loyal" kepada negara, domestikasi terjadi melalui kehidupan partai politik yang rapuh, penuh konflik, dan oleh karenanya tidak pernah memiliki posisi untuk menyaingi apalagi mengancam otoritas negara.

Dalam pada itu, pada tingkat ideologis domestikasi tidak kalah efektifnya telah menjadi terutama melalui pengaruh penerimaan "interpretasi" negara atas Pancasila sebagai azas tunggal bagi semua organisasi kemasyarakatan. Makna paling penting dari interpretasi yang dimaksud tentang konsensus nasional untuk menerima Pancasila sebagai azas tunggal adalah penerimaan azas konsensus dan monopoli negara atas hak untuk mendefinisikan bagaimana konsensus tersebut harus diwujudkan. Pada tingkat operasional, ia mengungkapkan dirinya di dalam penerimaan Garis-Garis Besar Haluan Negara (GBHN), bukan terutama di dalam fungsinya yang "positif" sebagai cetak biru program-program pembangunan akan tetapi lebih-lebih di dalam fungsinya yang "negatif" sebagai kendala bagi perumusan kebijakan publik oleh aktor lain di luar negeri (Macintyre, 1991: 29). Dengan cara demikian negara menjadi satu-satunya aktor politik yang memegang menopoli untuk menentukan apa yang boleh dan tidak boleh dilakukan oleh masyarakat. Ekses dari sosialisasi semuanya itu melalui program P4 (Pedoman Penghayatan dan Pengamalan Pancasila) telah menghasilkan nyaris semua orang, tidak terkecuali para cendekiawan, mengalami apa yang oleh Herbert Marcuse (Roszak, 1969: 14) disebut sebagai "desublimasi represif" berupa kapasitas untuk mengalami kepuasan atas semua yang mereka terima dari negara dengan cara yang menimbulkan penundukan dan melemahkan rasionalitas untuk me-lakukan penolakan. Dengan semua itu, pada tingkat ideologis domestikasi terjadi oleh karena penerimaan interpretasi seihak nagara atas Pancasila sebagai azas tunggal hanya terjadi pada tingkatnya sebagaj "ideologi" dan tidak di dalam maknanya sebagai "utopia" atau "social critics" di dalam pengertian Mannheim.

\section{Perkembangan Sosiologi di Indonesia}

Di hadapan latar belakang atau konteks politik yang demikian, dapatlah dimengerti mengapa perkembangan sosiologi selama ini di Indonesia sangat dikuasa oleh suatu "monisme" epistemologis dan teoritis tertentu. Di hadapan latar belakang atau 
konteks politik yang demikian, tidak sulit dimengerti mengapa pengaruh positivisme Perancis dan statisisme Amerika lebih menguasai perkembangan sosiologi, sementara sebaliknya fenomenologi Jerman dan strukturalisme (Marxist maupun non-Marxist) tidak banyak mewarnai karya-karya penelitian para ahli sosiologi di Indonesia akhir-akhir ini. Sebagai hasilnya, perkembangan sosiologi di Indonesia, terutama sesudah tahun 1970-an, lebih kuat mengungkapkan karakternya sebagai ilmu pengetahuan nomologis, dan kurang mengembangkan karakternya sebagai ilmu pengetahuan ideografis dan historis. Pada tingkat praktis, meminjam terminologi Alain Toraune (sebagaimana dikutip Bottomore, 1974), perkembangan sosiologi di Indonesia akhir-akhir ini lebih memainkan perannya sebagai the science of decision making untuk memecahkan masalah-masalah jangka pendek, dan kurang mewujudkan kapasitasnya sebagai the science of contestation untuk mewujudkan komitmen pada kemanusiaan melalui pemihakan pada yang lemah.

Di dalam hubungan itu sangat menarik, misalnya, untuk mengamati bagaimana issu pemribumian ilmu-ilmu sosial (indigenization of social science) yang marak pada pertengahan tahun 1970-an sebagai respon terhadap importasi positivisme ilmu-ilmu pengetahuan sosial barat di belakang ekspansi ekonomi negara-negara industri maju, melalui mekanisme korporatisasi kegiatan ilmu pengetahuan di dalam waktu yang singkat telah berubah mejadi gugatan terhadap pemakaian teori-teori kritis yang dipinjam dari para ahli ilmu-ilmu pengetahuan sosial dari negara-negara industri maju. Gugatan yang demikian bahkan datang dari para ahli ilmu sosial Indonesia sendiri, seperti yang sangat jelas menemukan pengungkapannya di dalam usulan hasil seminar yang diselenggarakan oleh
Fakultas Filsafat Universitas Gadjah Mada awal tahun 1980-an untuk menggunakan Pancasila sebagai orientasi etis pengembangan ilmu-ilmu pengetahuan sosial di Indonesia. Sangat menarik pula untuk menunjuk munculnya perkembangan spesialisasi sosiologi keluarga di dalam kurun waktu yang sangat pendek sebagai hasil komitmen organisasi profesi para ahli sosiologi (Ikatan Sosiologi Indonesia) untuk mendukung penyelenggaraan salah satu program pemerintah sebagai indikasi bias perkembangan sosiologi pada fungsinya sebagai the science of decision making.

Yang nampak pada peta perkembangan sosiologi di Indonesia seperti diuraikan di atas jelas terlalu sederhana, dan tidak menggambarkan nuansa-nuansa detil dari berbagai pilihan perspektif yang di anut oleh para ahli sosiologi Indonesia pada tingkat individual. Tidak nampak pula dari peta perkembangan sosiologi di atas adalah fase-fase perkembangan sosiologi di Indonesia yang dihasilkan oleh pengaruh perkembangan perspektif-perspektif sosiologi di Amerika Serikat dan Eropa pada berbagai kurun waktu pada para ahli sosiologi Indonesia ketika dan dari mana mereka mengambil pendidikan lanjut, Dilihat dari perspektif pembakaran yang demikian, perkembangan sosiologi di Indonesia dapat diidentifikasi sebagai perkembangan tiga kurun waktu dasawarsa 1960-an, dasawarsa 1970-an sampai 1980-an, dan pasca dasawarsa 1980-an.

Gambaran peta perkembangan sosiologi seperti diuraikan di atas, misalnya, lebih mengungkapkan perkembangan yang mengalir dari pengaruh pilihan perspektif para ahli sosiologi Indonesia yang memperoleh pendidikan lanjut di Amerika Serikat sampai dengan dawasarsa 1960-an: untuk menyebut Selo Soemardjan, Harsya Bachtiar, Umar Kayam, dan Sulaiman Sumardi sebagai beberapa diantara mereka yang 
pemikiran-pemikirannya paling berpengaruh. Pilihan mereka akan epistemologi positivisme dan teori struktural-fungsional yang sedang marak di Amerika Serikat sebagai akibat boom perkembangan Amerika Serikat pasca Perang Dunia II, dengan sedikit kesulitan untuk memasukkan Umar Kayam di dalamnya, memang cocok dengan pilihan ideologi pembangunanisme yang diambil pemerintah Orde Baru. Kurun waktu yang kedua ditandai oleh pengaruh pilihan perspektif strukturalisme, terutama dari varian sosiologi Marxis dan sosiologi kritis, dari para ahli sosiologi Indonesia yang memperoleh pendidikan lanjut di Amerika Serikat sepanjang dasawarsa 1970-an dan awal 1980-an, untuk menyebut antara lain Arief Budiman dan Loekman Soetrisno sebagai contohnya, ketika kemampuan positivisme dan struktur fungsional di negeri itu sedang digugat. Dalam pada itu, perkembangan sosiologi di Indonesia pada awal dasawarsa 1990-an, meskipun belum jelas benar perkembangannya, nampaknya sedang terjadi di bawah pengaruh perkawinan antara perspektif strukturalisme Marxis, sosiologi kritis aliran Farnkfurt, dan kebangkitan kembali sosiologi Webwrian.

Meskipun demikian, oleh kuatnya pengendalian korporatisme negara atas perkembangan ilmu pengetahuan sampai saat ini, perkembangan sosiologi di Indonesia sejauh ini masih sangat kuat dikuasai oleh peranannya sebagai instrumen pemgambilan keputusan daripada instrumen kontestasi. Jikalau perkembangan sosiologi di Indonesia di masa mendatang harus memberikan keseimbangan antara perannya sebagai instrumen untuk suatu piecemeal engineering bagi pemecahan masalah-masalah praktis jangaka pendek dan sebagai "kritik sosial" dan instrumen kontestasi yang memiliki potensi sosial ilmu pengetahuan bagi orientasi tindakan- tindakan "pencerahan", ja harus semakin terbuka terhadap pluralisme epistemologis dan metodologis. Sementara positivisme diperlukan untuk memberikan kemampuan sosiologi untuk memberikan sumbangan bagi pemecahan masalah-masalah jangka pendek, perkembangan sosiologi di indonesia di masa mendatang harus menghindarkan metodologi yang digunakan berkembang menjadi apa yang oleh Mills (1959) disebut sebagai "empirisme abstrak" (abstract empirisism): sebagai pengumpulan data tanpa tujuan. Itulah yang secara tipikal kita temukan ketika, terutama di dalam perkembangan sosiologi Amerika, positivisme yang demikian menggungkapkan dirinya ke dalam bentuk "statistisme" dan "matematisme". Pada saat yang sama perkembangan sosiologi di Indonesia di masa mendatang harus terbuka untuk beragam konsep, teori, dan metodologi dari berbagai tradisi epistemologi.

\section{Daftar Pustaka}

Dahrendorf, Ralf, "Sociology and Sociologist", dalam Raft Dahrendorf, Essays in the Theory of Society, Stanford University Press, 1968.

Habermas, J., sebagaimana dikutip oleh Ralf Dahrendorf, dalam Essays in the Theory of Society, Stanford University Press, 1968.

Jackson, Karl D., "Bureaucratic Polity", dalam Karl D. Jackson and Lucien W. Pey (Eds.), Political Power and Communications in Indonesia (Berkeley: California Univ. Press, 1978).

King, Dwight Y., Social Mobilization, Associational Life, Interest Mediation and Political Caleavage in Indonesia. Dept. of Political Science 
Topik: Domestikasi Peran Cendekiawan..., Nasikun

Norther Illinnois Univ. (Disertasi tidak Mas'oed, Mohtar, The Indonessian Econoditerbitkan, 1978).

Konrad, George and Ivan Szelenyi, The Intellectuals on the Road to Class Power, Harcourt Brace Jovanovich, 1979.

Mannheim, Karl, Ildeology and Utopia, Harcourt, Brace, 1936.

my and Political Structure During The Early New Order, 1966-1971, Ann Arbor: University Microfils International, 1983 (Disertasi tidak diterbitkan).

Mills, C. Wright, The Sociological Imagination, Oxford University Press, 1959.

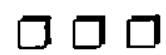

